\title{
Off-label use of drugs administered by enteral feeding tubes in an Intensive Care Unit in Fortaleza, Brazil
}

\author{
Gabriela Araujo de ABREU ${ }^{1}$, Elana Figueiredo CHAVES ${ }^{1}$, José Alcântara NETO², Lívia Porto MOREIRA ${ }^{1}$, Johann Vargas SILVA ${ }^{3}$, \\ Andreína Fontenele TEIXEIRA, Marjorie Moreira GUEDES², Milena Portela BESERRA ${ }^{2}$
}

${ }^{1}$ Programa de Residência Integrada Multiprofissional em Atenção Hospitalar à Saúde, Hospital Universitário Walter Cantídio, Universidade Federal do Ceará, Fortaleza, Brasil; ${ }^{2}$ Hospital Universitário Walter Cantídio, Fortaleza, Brasil; ${ }^{3}$ Programa de Residência Médica em Terapia Intensiva, Hospital Universitário Walter Cantídio, Universidade Federal do Ceará, Fortaleza, Brasil

Corresponding author: Abreu GA, ga.abreu@gmail.com

Submitted: 13-01-2021 Resubmitted: 07-03-2021 Accepted: 07-03-2021

Peer review: blind reviewer and Juliana Miranda Ferreira

\begin{abstract}
Objective: To analyze the prescription profile of drugs administered through enteral feeding tubes in an adult intensive care unit and gather recommendations for their safe administration. Methods: This is a descriptive and cross-sectional study conducted with adult critical clinical patients of a university hospital in Fortaleza-Ceará from March to May 2018. We performed analyses of patients' medical records and prescriptions regarding drugs, pharmaceutical presentations and the possibility of administration through enteral tubes. Results: 489 prescriptions containing 1914 items were evaluated, from which $16.6 \%(n=318)$ through tubes. Medicines for the cardiovascular system (34.6\%), nervous system (27.4\%) and digestive system and metabolism (15.1\%) were the most predominant, with an average of 5.8 (DP: 4.2) different per patient. Regarding the pharmaceutical presentation, oral solids were frequently prescribed via enteral tube (67.9\%), especially risperidone (8.8\%), carvedilol $(8.3 \%)$ and amiodarone (7.9\%). There were contraindications for administration through tubes in $21.6 \%$ of solid oral formulations, while there were alternative standardized pharmaceutical forms in the hospital for $43.1 \%$. In addition, substitution for liquid preparations from the market were possible in $43.1 \%$. Among those to which there were no alternative formulations, drugs targeting the cardiovascular system prevailed (52.2\%). A table with guidelines for the proper administration of the prescribed solid medications was elaborated then. Conclusion: Solid oral medications were frequently prescribed through enteral tubes, especially those for the cardiovascular system without alternative formulations, which shows the need for guidelines to promote the safety of this process.
\end{abstract}

Keywords: pharmaceutical preparations; drug administration routes; enteral nutrition; critical care; intensive care units; patient safety.

\section{Uso off-label de medicamentos por sonda de nutrição enteral em Unidade de Terapia Intensiva em Fortaleza, Brasil}

\section{Resumo}

Objetivo: Analisar o perfil de prescrição de medicamentos por sonda de nutrição enteral em unidade de terapia intensiva adulto e reunir recomendações para uma administração segura. Métodos: Trata-se de estudo descritivo e transversal realizado com pacientes críticos clínicos adultos de um hospital universitário em Fortaleza-Ceará, de março a maio de 2018. Foi realizado a partir da análise do prontuário e das segundas vias das prescrições, do Serviço de Farmácia, quanto a fármacos, apresentações farmacêuticas e possibilidade de uso por sonda enteral. Resultados: Avaliou-se 489 prescrições com 1914 medicamentos, sendo 16,6\% destes prescritos por sonda. Predominaram medicamentos para sistema cardiovascular (34,6\%), sistema nervoso $(27,4 \%)$ e sistema digestivo e metabolismo (15,1\%), com média de 5,8 (DP: 4,2) fármacos por paciente. Quanto à apresentação farmacêutica, observou-se alta frequência de prescrição de sólidos orais $(67,9 \%)$ via sonda, sendo os mais prescritos a risperidona (8,8\%), o carvedilol (8,3\%) e a amiodarona (7,9\%). Existia contraindicação para administração por sonda para $21,6 \%$ das formulações sólidas orais, havendo forma farmacêutica alternativa padronizada no hospital para $43,1 \%$ dos sólidos orais prescritos e possibilidade de substituição por preparação líquida existente no mercado para 43,1\% deles. Entre os que não possuíam formulação alternativa, prevaleceram medicamentos para o sistema cardiovascular (52,2\%). A partir dos resultados obtidos, elaborou-se uma tabela com orientações para administração adequada dos medicamentos sólidos prescritos. Conclusão: Houve alta frequência de prescrição por sonda enteral de medicamentos sólidos orais, especialmente daqueles para o sistema cardiovascular sem formulações alternativas, evidenciando-se a necessidade de orientações para promoção da segurança dos envolvidos no processo.

Palavras-chave: preparações farmacêuticas; vias de administração de medicamentos; nutrição enteral; cuidados críticos; unidades de terapia intensiva; segurança do paciente. 


\section{Introduction}

In critically-ill patients, malnutrition and dysphagia are common, which is why the use of enteral nutrition tubes (ENTs) for the administration of diet is frequent in those with functioning gastrointestinal tract. ${ }^{1,2}$ This route is also used for the administration of medications and is often the preferred choice for being less risky and uncomfortable, as well as more economical in relation to the parenteral routes. ${ }^{3}$ However, most of the preparations for oral use are not licensed for administration by ENT; there are few studies that demonstrate the effectiveness and safety of the off-label use of these formulations., ${ }^{4,5}$

Off-label use of medications refers to their use differently from that approved in the package leaflet by the country's health agency, with respect to the patient's age group, indication, dose and administration route, among other aspects. ${ }^{6}$ It is quite common in several patient populations, including adults in intensive care units (ICUs). ${ }^{7}$ This use is not illegal, it is not necessarily incorrect, and can be predicted and recommended in institutional protocols and international consensus. ${ }^{6,8}$ However, this process requires greater attention from the health professionals, as it can increase the frequency of adverse events. 7,9

Off-label use of medication by tubes can cause adverse events secondary to the transformation of solid oral preparations into liquids, such as therapeutic ineffectiveness, tube obstruction and toxicity, which can result in injury to the patient and in an increase in the cost associated with health care. The process of shredding solid drugs, for example, can bring an occupational risk to the handler, especially when the drugs are teratogenic, cytotoxic or hormones. On the other hand, the administration of liquid formulations by enteral nutrition tubes, such as syrups and suspensions, can also result in adverse events to the patients since, in case of high osmolarity and viscosity, there can be tube obstructions. . $^{4,5}, 10$

In this context, it is necessary to evaluate the off-label use of medications, considering that the ENT was made for the administration of liquids, that many medicines do not have a liquid presentation available on the market, and that there are few national studies evaluating the use of ENT drugs in adults admitted to an ICU. Thus, the objective of this study was to characterize the prescription of drugs by ENTs in an adult ICU, as well as to gather recommendations for safe administration, more specifically of the solid formulations.

\section{Methods}

This is a cross-sectional and descriptive study carried out to identify and evaluate the drugs used by ENTs in patients of a clinical ICU for adults, at the Walter Cantídio University Hospital, in Fortaleza, Brazil, from March to May 2018. The study was elaborated according to the regulatory guidelines for research involving human beings and was approved by the hospital's Ethics Committee, under opinion number 2,781,072.

The study hospital is a tertiary care unit linked to the Unified Health System (Sistema Único de Saúde, SUS) network, which did not have an electronic prescription system in the evaluated inpatient unit or an institutional protocol for the administration of medications by tubes, at the time of data collection. The clinical ICU consists of eight beds and is served by a multi-professional team, including physicians, nurses, nursing technicians, physiotherapists, speech therapists, nutritionists, social workers and pharmacists.

A scheme of the study's methodological flow is shown in Figure 1. The study included patients aged 18 years old and over, who were admitted to the ICU for at least 48 hours and who were prescribed at least one medication per ENT. Medications prescribed as "if necessary" or "at medical discretion" were not included in the study due to lack of data, especially regarding indication. The data were collected in a specific form, from the patient's medical record, and from the second copies of the prescriptions filed at the pharmacy. These included patient data such as gender, age, ICU outcome (discharge, death or hospital transfer), and data on prescriptions such as the medication prescribed, form of prescription and pharmaceutical presentation. The patients were classified according to their age into aged individuals (age $\geq 60$ years old) and not aged individuals ( $<60$ years old), in order to describe the demographic profile of the population studied. The scores of APACHE II (Acute Physiology and Chronic Health Disease Classification System II), a disease severity classification system in adult patients admitted to ICUs, ${ }^{11}$ and SOFA (Sequential Organ Failure Assessment), a tool for assessing the severity of morbidity and prediction of mortality in ICU patients, ${ }^{12}$ were calculated in the first 24 hours of admission by the medical team. The drugs prescribed were classified according to the Anatomical Therapeutic Chemical Classification (ATC) levels 1 and 2, which correspond to the anatomical group and the therapeutic group, respectively. Categorization of the Potentially Dangerous Medications (PDMs) was also performed, established by the Institute for Safe Medication Practices (ISMP) - an independent, non-profit and non-governmental organization that works to promote safe practices in the use of medications and health products in Brazil. ${ }^{13,14}$

Figure 1. Methodological flow of the study conducted in a clinical intensive care unit for adults of a teaching hospital in Fortaleza, Brazil, from March to June 2018.

\begin{tabular}{|c|c|c|c|}
\hline \multicolumn{4}{|c|}{ Inclusion of the patients } \\
\hline$\geq 18$ years old & $\begin{array}{l}\text { Prescription } \geq 1 \text { medi } \\
\text { cation per ENT }\end{array}$ & $\begin{array}{l}\text { Monitored by a } \\
\text { pharmacist }\end{array}$ & $\begin{array}{l}\text { Medical chart } \\
\text { available for } \\
\text { consultation }\end{array}$ \\
\hline \multicolumn{4}{|c|}{ Data collection } \\
\hline \multicolumn{2}{|c|}{$\begin{array}{l}\text { 1. Patient } \\
\text { - Age and gender } \\
\text { - APACHE II and SOFA } \\
\text { - ICU clinical outcome }\end{array}$} & \multicolumn{2}{|c|}{$\begin{array}{l}\text { 2. Medications } \\
\text { - Active ingredient } \\
\text { - Pharmaceutical presentation } \\
\text { - Administration route }\end{array}$} \\
\hline \multicolumn{4}{|c|}{ र' } \\
\hline \multicolumn{4}{|c|}{ Constitution of the databases } \\
\hline
\end{tabular}

Analysis of information on the inserts of the medications and classification as off-label

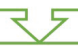

Literature review on the recommendation for the administration of medications through a tube

Elaboration of guidance for administration ए

Estimation of the prevalence of medication administration by tube 
Since doubts about the administration of medications by tubes can be common in the clinical practice, a table was elaborated that gathers necessary recommendations to guarantee the safety and effectiveness of the administration of solid medications by ENTs. To such end, a literature review was conducted by means of searches in the SciELO and PubMed databases. As strategies for information search, the following descriptors were identified and defined: enteral feeding tube, enteral nutrition and drug administration). The descriptors were used with and without the inclusion of the Boolean operator and. Articles from 2008 to 2019 were selected in Portuguese, Spanish and English that addressed the use of medications by ENTs in adult patients. The "Do not crush list"15 and "Enteral feeding tubes and enteral delivery"16 lists from the Micromedex ${ }^{\circledR}$ database, and the "Oral dosage forms that should not be crushed" 17 list from the Institute for Safe Medication Practices (ISMP) were used. Books, guides, the electronic bulletin from the National Health Surveillance Agency (Agência Nacional de Vigilância Sanitária, ANVISA) ${ }^{18}$ and other relevant publications on the topic ${ }^{19-26}$ were also used as a complementary bibliography. Such bibliographies were consulted in order to obtain data on pharmaceutical form, possibility of administration by tube, use recommendations, existence of interactions with enteral nutrition, occupational risks, pharmacokinetic changes. In addition to that, the existence of an alternative pharmaceutical form was found in the hospital and in the Brazilian market, for use by ENT, as well as the existence of a pharmaceutical form for administration by alternative routes.

The data were collected and analyzed by pharmacists in Microsoft Excel ${ }^{\oplus}$, version 2016. The numerical variables were presented as mean and standard deviation and the categorical variables were exposed as frequency, in order to investigate risk factors associated with the off-label prescription of drugs by tube. A significance level of $5 \%$ was adopted. ${ }^{7}$ When investigating the association between the variables, Fisher's exact test was performed, due to the small sample size, in the Graph Pad Prism ${ }^{\circledR}$ statistical program, version 7.0d (USA).

\section{Results}

A total of 37 patients were included in the study, of which 489 prescriptions were evaluated with at least one item per enteral tube. Female patients $(59.5 \%, \mathrm{n}=22)$, not aged $(51.3 \%, \mathrm{n}=19)$ prevailed, with a discharge outcome $(70.3 \%, n=26)$ and with APACHE II and SOFA clinical importance scores of lesser severity. The mean age was 56.9 (SD: 16.7) There was no statistically significant association between gender, age, outcome and scores of clinical importance and the existence or not of an alternative for administration by ENT (Table 1).

A total of 1,914 medications were prescribed for these patients, of which $16.6 \%(n=318)$ were administered by ENT. Of these, $68.9 \%(n=219)$ were prescribed for the first time after admission to the ICU. 61 different ENT drugs were prescribed, belonging to 10 classes according to the ATC classification, level 1.
Table 1. Demographic and clinical data of the study patients hospitalized in a clinical intensive care unit for adults of a teaching hospital in Fortaleza, Brazil, from March to June 2018.

\begin{tabular}{|c|c|c|c|c|}
\hline Information & $\begin{array}{l}\text { All } \\
N=318\end{array}$ & $\begin{array}{l}\text { With } \\
\text { alternative } \\
N=112\end{array}$ & $\begin{array}{l}\text { Without } \\
\text { alternative }^{5} \\
N=106\end{array}$ & p-value \\
\hline Female gender ${ }^{1} \mathrm{n}(\%)$ & $213(67.0)$ & $72(33.0)$ & $78(35.8)$ & 0.147 \\
\hline $\begin{array}{l}\text { Older adult ( } \geq 60 \text { years } \\
\text { old) })^{1,2}\end{array}$ & $171(53.8)$ & $63(28.9)$ & $73(33.5)$ & 0.069 \\
\hline \multicolumn{5}{|c|}{ Clinical importance scores $\mathrm{n}(\%)$} \\
\hline APACHE $\| \leq 25^{3}$ & $264(83.0)$ & 90 (41.3) & 94 (43.1) & \multirow{2}{*}{0.097} \\
\hline APACHE $\|>25^{3}$ & $54(17.0)$ & $22(10.1)$ & $12(5.5)$ & \\
\hline SOFA $\leq 12^{4}$ & $315(99.1)$ & $111(50.9)$ & $106(48.6)$ & \multirow{2}{*}{1.000} \\
\hline SOFA $>12^{4}$ & $3(0.9)$ & $1(0.5)$ & $0(0)$ & \\
\hline \multicolumn{5}{|l|}{ Outcome n (\%) } \\
\hline Discharge & 254 (79.9) & $88(40.4)$ & $82(37.6)$ & \multirow{2}{*}{0.871} \\
\hline Death & 64 (20.1) & $24(11.0)$ & $24(11.0)$ & \\
\hline
\end{tabular}

${ }^{1}$ Dichotomous variable for which the results of only one category were presented. ${ }^{2}$ In Brazil, an aged individual is defined as a person aged 60 years old or over ${ }^{49} .{ }^{3}$ Acute Physiology and Chronic Health Evaluation. The APACHE II stratification was applied randomly, considering the risk of mortality greater than $50 \%$ for values above $25 .{ }^{11}{ }^{4}$ Organ Failure Assessment. The SOFA stratification was applied randomly, considering the estimate of organic failure above $50 \%$ for values over $12 .{ }^{125} \mathrm{In}$ this analysis, only alternatives for the solid pharmaceutical forms were considered. ${ }^{6}$ Standard Deviation (SD).

There was predominance of prescriptions for drugs of the cardiovascular system (34.6\%; $\mathrm{n}=110)$, nervous system $(27.4 \%$; $\mathrm{n}=87$ ), and digestive system and metabolism (15.1\%; $n=48)$ groups (Table 2). In the first group, the highest frequency of prescription was medication for cardiac therapy $(25.4 \%, n=28)$, which includes antirhythmic drugs, cardiac glycosides and vasodilators, among others; the second most frequent was that of beta-blocking agents $(20.9 \%, n=23)$. Of the nervous system medications, the most frequent were psycholeptics $(50.6 \%, n=54)$ and antiepileptics (34.5\%, $\mathrm{n}=30)$; antispasmodic, anticholinergic and propulsive agents $(41.7 \%, \mathrm{n}=20)$; and laxatives $(33.3 \%, \mathrm{n}=16)$ were the most commonly prescribed for the digestive system and metabolism.

The mean of different drugs administered by tube was 5.8 (SD: 4.2) per patient (varying from 1 to 16). The most prescribed drugs were clonazepam $(9.4 \%, n=20)$, risperidone $(6.0 \%, n=19)$ and carvedilol $(5.7 \%, n=18)$ (Table 2$)$. Of the drugs used by tube, $13.5 \%(n=43)$ were PDMs. Of these, amiodarone $(39.5 \%, n=17)$ was the most prevalent, followed by diazepam (18.6\%, $n=8)$, potassium chloride in syrup $(9.3 \%, n=4)$ and tacrolimus $(9.3 \%$, $n=4)$.

Regarding the items prescribed by tube, $67.9 \%(n=216)$ were oral solids, and $88.3 \%(n=190)$ of these were tablets. Among the patients, $91.4 \%(n=32)$ received prescriptions for 51 drugs in solid dosage forms by ENT, with a mean of 4.5 (SD: 3.4 ) drugs in solid preparations per patient (ranging from 1 to 13 ), while $8.6 \%$ $(n=3)$ received other types of tube formulations. Among the most frequently prescribed oral solids were risperidone $(8.8 \%, n=19)$, carvedilol $(8.3 \%, \mathrm{n}=18)$, amiodarone $(7.9 \%, \mathrm{n}=17)$, amlodipine $(6.9 \%, n=15)$, hydralazine $(6.9 \%, n=15)$ and acetylsalicylic acid $(5.6 \%, n=12)$. The presentations of the medications used and the types of tablets prescribed with the frequency of prescription for each are detailed in Table 2. 
Table 2. Anatomical Therapeutic Chemical (ATC) classification of the most prescribed drugs by enteral nutrition tube in an adult intensive care unit in Fortaleza, Brazil, from March to June 2018.

\begin{tabular}{|c|c|}
\hline Information & $n(\%)$ \\
\hline \multicolumn{2}{|l|}{ Most prescribed medication by tube } \\
\hline Cardiovascular system & $110(34.6)$ \\
\hline Carvedilol & $18(5.7)$ \\
\hline Amiodarone & $17(5.4)$ \\
\hline Amlodipine & $15(4.7)$ \\
\hline Hydralazine & $15(4.7)$ \\
\hline Nervous system & $87(27.4)$ \\
\hline Clonazepam & $20(6.3)$ \\
\hline Risperidone & $19(6.0)$ \\
\hline Haloperidol & $15(4.7)$ \\
\hline Digestive system and metabolism & $48(15.1)$ \\
\hline Lactulone & $16(5.0)$ \\
\hline Simethicone & $14(4.4)$ \\
\hline Domperidone & $6(1.9)$ \\
\hline Antiparasitics, insecticides and repellent products & $20(6.3)$ \\
\hline Benzoilmetronidazole & $11(5.1)$ \\
\hline Ivermectin & $5(1.6)$ \\
\hline Secnidazole & $3(0.9)$ \\
\hline Blood and hematopoietic organs & $15(4.7)$ \\
\hline Acetylsalicylic acid & $12(3.8)$ \\
\hline Folic acid & $1(0.3)$ \\
\hline Vitamin B12 & $1(0.3)$ \\
\hline Clopidogrel & $1(0.3)$ \\
\hline $\begin{array}{l}\text { Systemic hormonal preparations, excluding sex } \\
\text { hormones and insulins }\end{array}$ & $13(4.1)$ \\
\hline Prednisolone & $6(1.9)$ \\
\hline Levothyroxine & $4(1.3)$ \\
\hline Prednisone & $3(0.9)$ \\
\hline General anti-infectives for systemic use & $10(3.1)$ \\
\hline Sulfamethoxazole + trimethoprim & $3(0.9)$ \\
\hline Metronidazole & $3(0.9)$ \\
\hline Rifampicin & $2(0.6)$ \\
\hline Vancomycin & $2(0.6)$ \\
\hline Antineoplastic and immunomodulating agents & $8(2.5)$ \\
\hline Tacrolimus & $4(1.3)$ \\
\hline Mycophenolate mofetil & $3(0.9)$ \\
\hline Mycophenolate sodium & $1(0.3)$ \\
\hline Respiratory system & $5(1.6)$ \\
\hline Loratadine & $5(1.6)$ \\
\hline Musculoskeletal system & $2(0.6)$ \\
\hline Ibuprofen & $2(0.6)$ \\
\hline \multicolumn{2}{|l|}{ Prescribed presentations } \\
\hline Tablet & 190 (59.7) \\
\hline Immediate-release tablet & $153(80.5)$ \\
\hline Film-coated tablet & $27(14.2)$ \\
\hline Sublingual tablet & $5(2.6)$ \\
\hline Extended-release coated tablet & $4(2.1)$ \\
\hline Chewable tablet & $1(0.5)$ \\
\hline Oral solution/drops & $34(10.7)$ \\
\hline Syrup & $22(6.9)$ \\
\hline Oral solution & $18(5.7)$ \\
\hline Oral suspension & $17(5.3)$ \\
\hline Dragée & $15(4.7)$ \\
\hline Capsule & $10(3.1)$ \\
\hline Injectable solution & $9(2.8)$ \\
\hline Powder for injectable solution & $2(0.6)$ \\
\hline Powder for extemporaneous preparation & $1(0.3)$ \\
\hline
\end{tabular}

It was verified that $21.6 \%(n=11)$ of the oral solids administered by ENT had some contraindication for use by this route. It was observed that, for $43.1 \%(n=22)$, there was a standardized alternative pharmaceutical presentation in the hospital. However, there were liquid presentations for $25.5 \%(n=13)$ and intravenous forms for $25.5 \%(n=13)$ of the cases. Assessing the existence of a liquid pharmaceutical form in the Brazilian market, there was a substitution possibility for $43.1 \%(n=22)$ of the prescribed drugs.

During the study period, four non-standard medications were prescribed in the hospital: atorvastatin, escitalopram, levetiracetam and racecadotril, which were used in solid forms due to acquisition by donation, loan or exchange with other hospitals, even though there are liquid presentations on the market for three of them. Among those that did not have an alternative formulation, medications for the cardiovascular system prevailed $(52.2 \%, \mathrm{n}=12)$. From these results, a table was created with information for the proper administration of the prescribed solid pharmaceutical forms (Table 3).

\section{Discussion}

In this study, it was possible to observe a high frequency of offlabel prescription of drugs that act on the cardiovascular system due to administration by enteral tube, with immediate release tablets with no alternative formulations predominating. To our knowledge, this is the first study to evaluate this type of offlabel drug use in critically-ill adult patients from Ceará with the provision of an administration guidance table. Furthermore, it is noteworthy that the evaluation of the off-label use of medications in critically-ill adult patients is scarce and that the few Brazilian studies on the evaluation of this use involve pediatric and neonatal populations. ${ }^{27,28}$

The administration of medications via enteral nutrition tubes involves several aspects related to the patient and to the medication that challenge the assistance team. In most cases, the responsibility for this practice is not shared by the pharmaceutical industry and decision-making is left to the inter-professional assistance team. In addition to that, the lack of information about the practice, the unavailability of alternative liquid forms on the market, and the inconvenience of other administration routes are frequent problems in the hospital routine and can cause medication errors ${ }^{5}$. In view of this scenario, in which doubts about the administration of medications by tubes are common, the elaboration of the table for the administration of medications by tubes was elaborated with the objective of gathering the necessary recommendations to ensure the safety and effectiveness of drug therapy administered via tubes, especially in intensive care.

The frequency of $16.6 \%$ of medication prescriptions per tube in this study is comparable to that found in a study in the ICU environment of another Brazilian teaching hospital. ${ }^{29}$ In addition to that, the analysis of the ENT prescription profile allowed observing a predominance of drugs that act in the cardiovascular system, nervous system and digestive system and metabolism, a result similar to that found in a study carried out in an adult ICU in Rio de Janeiro. ${ }^{30}$ This reflects the profile of the patients admitted to the unit: with a high prevalence of chronic cardiovascular diseases and who frequently present conditions such as delirium and constipation. ${ }^{31-33}$ 
Table 3. Information for the proper administration of the solid pharmaceutical forms prescribed by enteral tube for patients in an intensive care unit for adults of a teaching hospital in Fortaleza, Brazil, from March to June 2018 (N=216). (Continua)

\begin{tabular}{|c|c|c|c|c|c|c|c|}
\hline Drug & Pr. $^{1}$ & $\begin{array}{l}\text { Admin. } \\
\text { tube }^{2}\end{array}$ & $\begin{array}{l}\text { Preval. }{ }^{3} \\
\mathrm{n}(\%)\end{array}$ & Guidelines & $\begin{array}{l}\text { Alternative to } \\
\text { ENT }^{4}\end{array}$ & Braz. mar. pres. ${ }^{5}$ & Altern. route ${ }^{6}$ \\
\hline $\begin{array}{l}\text { Acetylsalicylic } \\
\text { acid }\end{array}$ & $\mathrm{t}$ & Yes & $12(5.6)$ & $\begin{array}{l}\text { Disperse in } 10 \mathrm{~mL} \text { of DW. }{ }^{9} \text { Administer together } \\
\text { with } \mathrm{NE}^{10} \text { to reduce gastrointestinal effects. }\end{array}$ & No & No & No \\
\hline Folic acid & $\cot$ & Yes & $1(0.5)$ & Disperse in $10 \mathrm{~mL}$ of DW. ${ }^{9}$ & No & No & No \\
\hline Albendazole & ct & Yes & $1(0.5)$ & Disperse in $10 \mathrm{~mL}$ of DW. ${ }^{9}$ & $\begin{array}{l}\text { Yes } \\
\text { (oral suspension) }\end{array}$ & $\begin{array}{l}\text { Yes } \\
\text { (oral suspension) }\end{array}$ & No \\
\hline Amiodarone & $\mathrm{t}$ & Yes & $17(7.9)$ & $\begin{array}{l}\text { Disperse in } 20 \mathrm{~mL} \text { of DW. }{ }^{9} \text { The drug is } \\
\text { photosensitive. }\end{array}$ & No & No & Yes $\left(\mathrm{IV}^{12}\right)$ \\
\hline Amlodipine & $\mathrm{t}$ & Yes & $15(6.9)$ & Disperse in $10 \mathrm{~mL}$ of DW. ${ }^{9}$ & No & No & No \\
\hline Atenolol & $\mathrm{t}$ & Yes & $2(0.9)$ & $\begin{array}{l}\text { Disperse in } 10 \mathrm{~mL} \text { of DW. }{ }^{9} \text { Administer } \\
1 \mathrm{~h} \text { before or } 2 \mathrm{~h} \text { after } \mathrm{NE}^{10} \text {, as it reduces } \\
\text { bioavailability by up to } 20 \% \text {. }\end{array}$ & No & No & No \\
\hline Atorvastatin & $\cot$ & Yes & $2(0.9)$ & $\begin{array}{l}\text { Disperse in } 10 \mathrm{~mL} \text { of DW. }{ }^{9} \text { It is photosensitive } \\
\text { and little soluble in water. }\end{array}$ & No & No & No \\
\hline Captopril & $\mathrm{t}$ & Yes & $6(2.8)$ & $\begin{array}{l}\text { Disperse in } 10 \mathrm{~mL} \text { of } \mathrm{DW} \cdot{ }^{9} \mathrm{Administer} \\
1 \mathrm{~h} \text { before or } 2 \mathrm{~h} \text { after } \mathrm{NE}^{10} \text {, as it reduces } \\
\text { bioavailability from } 30 \% \text { to } 40 \% \text {. }\end{array}$ & No & No & No \\
\hline Carvedilol & $\mathrm{t}$ & Yes & $18(8.3)$ & $\begin{array}{l}\text { Disperse in } 10 \mathrm{~mL} \text { of DW. }{ }^{9} \text { The higher the dose, } \\
\text { the longer the time to disperse, preferentially } \\
\text { administer EN. }{ }^{10}\end{array}$ & No & No & No \\
\hline Citalopram & $\cot$ & Yes & $1(0.5)$ & Disperse in $10 \mathrm{~mL}$ of $A D^{9}$ (dispersion is slow). & No & No & No \\
\hline Clonazepam & $\mathrm{t}$ & Yes & $20(9.2)$ & Disperse in $10 \mathrm{~mL}$ of DW. ${ }^{9}$ & $\begin{array}{l}\text { Yes } \\
\text { (oral sol./drop) }\end{array}$ & $\begin{array}{l}\text { Yes } \\
\text { (oral sol./drop) }\end{array}$ & No \\
\hline Clonidine & $\mathrm{t}$ & Yes & $4(1.8)$ & Disperse in $10 \mathrm{~mL}$ of DW. ${ }^{9}$ & No & No & Yes $\left(\mathrm{IV}^{12}\right)$ \\
\hline Clopidogrel & $\cot$ & Yes & $1(0.5)$ & $\begin{array}{l}\text { Grind and disperse in } 10 \mathrm{~mL} \mathrm{DW} .{ }^{9} \text { Administer } \\
\text { together with } \mathrm{NE}^{10} \text { to reduce gastrointestinal } \\
\text { effects. }{ }^{11}\end{array}$ & No & No & No \\
\hline Diazepam & $\mathrm{t}$ & Yes & $8(3.7)$ & Disperse in $10 \mathrm{~mL}$ of DW. ${ }^{9}$ & No & No & Yes $\left(\mathrm{IV}^{12}\right)$ \\
\hline Digoxin & $\mathrm{t}$ & Yes & $1(0.5)$ & $\begin{array}{l}\text { Disperse in } 10 \mathrm{~mL} \text { of DW. }{ }^{9} \text { Liquid formulation } \\
\text { is preferable. Incompatible with diets high in } \\
\text { fibers. }\end{array}$ & Yes (elixir) & Yes (elixir) & No \\
\hline Diltiazem & ert & No & $1(0.5)$ & Replace medication. & No & No & No \\
\hline $\begin{array}{l}\text { Isosorbide } \\
\text { dinitrate } 10 \mathrm{mg}\end{array}$ & $\mathrm{t}$ & No & $3(1.4)$ & $\begin{array}{l}\text { Risk of tube obstruction. Sublingual option } \\
\text { recommended, which can have its effect } \\
\text { reduced. }\end{array}$ & No & No & No \\
\hline Enalapril & $\mathrm{t}$ & Yes & $1(0.5)$ & Disperse in $10 \mathrm{~mL}$ of DW. ${ }^{9}$ & No & No & No \\
\hline Escitalopram & $\cot$ & No & $2(0.9)$ & $\begin{array}{l}\text { There are no data available in the literature. } \\
\text { Prefer liquid formulation. }\end{array}$ & No & $\begin{array}{l}\text { Yes } \\
\text { (oral solution) }\end{array}$ & No \\
\hline Spironolactone & $\mathrm{t}$ & Yes & $6(2.8)$ & Disperse in $10 \mathrm{~mL}$ of DW. ${ }^{9}$ & No & No & No \\
\hline Phenobarbital & $\mathrm{t}$ & No & $2(0.9)$ & Prefer liquid formulation. & $\begin{array}{l}\text { Yes } \\
\text { (oral sol./drop) }\end{array}$ & $\begin{array}{l}\text { Yes } \\
\text { (oral sol./drop) }\end{array}$ & Yes $\left(\mathrm{IV}^{12}\right)$ \\
\hline Fluoxetine & cap & Yes & $2(0.9)$ & $\begin{array}{l}\text { Disperse the contents of the capsule in } 20 \mathrm{~mL} \\
\text { of } A D^{9} \text { and administer immediately to reduce } \\
\text { the risk of degradation. }\end{array}$ & No & $\begin{array}{l}\text { Yes (oral sol./ } \\
\text { drop) }\end{array}$ & No \\
\hline Hydralazine & dg & Yes & $15(6.9)$ & $\begin{array}{l}\text { Grind and disperse in } 10 \mathrm{~mL} \text { of DW. }{ }^{9} \text { Grinding } \\
\text { degrades the drug. }\end{array}$ & No & No & Yes $\left(\mathrm{IV}^{12}\right)$ \\
\hline Ibuprofen & $\cot$ & Yes & $2(0.9)$ & $\begin{array}{l}\text { Disperse in } 10 \mathrm{~mL} \text { of DW. }{ }^{9} \text { Prefer liquid } \\
\text { formulation. Administer together with } \mathrm{NE}^{10} \\
\text { to reduce gastrointestinal effects; serum } \\
\text { concentration is reduced. }\end{array}$ & $\begin{array}{l}\text { Yes (oral } \\
\text { suspension) }\end{array}$ & $\begin{array}{l}\text { Yes } \\
\text { (oral suspension) }\end{array}$ & No \\
\hline Ivermectin & $\mathrm{t}$ & Yes & $5(2.3)$ & Disperse in $20 \mathrm{~mL}$ of DW. ${ }^{9}$ & No & No & No \\
\hline Levetiracetam & $\cot$ & Yes & $1(0,5)$ & $\begin{array}{l}\text { Disperse in } 10 \mathrm{~mL} \text { of } \mathrm{AD}^{9} \text { and administer } \\
\text { immediately. Prefer liquid formulation. }\end{array}$ & No & $\begin{array}{l}\text { Yes } \\
\text { (oral solution) }\end{array}$ & No \\
\hline Levothyroxine & $\mathrm{t}$ & Yes & $4(1.8)$ & $\begin{array}{l}\text { Disperse in } 10 \mathrm{~mL} \text { of DW. }{ }^{9} \text { Administer } 1 \mathrm{~h} \\
\text { before or } 2 \mathrm{~h} \text { after the diet. }\end{array}$ & No & No & No \\
\hline Loratadine & $\mathrm{t}$ & Yes & $5(2.3)$ & $\begin{array}{l}\text { Disperse in } 10 \mathrm{~mL} \text { of } \mathrm{DW} \cdot{ }^{9} \text { Administer } 1 \mathrm{~h} \\
\text { before or } 1 \mathrm{~h} \text { after the diet. Stop the diet } 30 \\
\text { minutes before and after if the tube is in a } \\
\text { gastric position. }\end{array}$ & Yes (syrup) & Yes (syrup) & No \\
\hline Losartan & $\cot$ & Yes & $3(1.4)$ & Disperse in $15 \mathrm{~mL}$ of DW. ${ }^{9}$ & No & No & No \\
\hline Methadone & $\mathrm{t}$ & Yes & $3(1.4)$ & Disperse in $10 \mathrm{~mL}$ of DW. ${ }^{9}$ & No & No & Yes $\left(\mathrm{IV}^{12}\right)$ \\
\hline
\end{tabular}


Table 3. Information for the proper administration of the solid pharmaceutical forms prescribed by enteral tube for patients in an intensive care unit for adults of a teaching hospital in Fortaleza, Brazil, from March to June 2018 (N=216).(Conclusão)

\begin{tabular}{|c|c|c|c|c|c|c|c|}
\hline Drug & Pr. $^{1}$ & $\begin{array}{l}\text { Admin. } \\
\text { tube }^{2}\end{array}$ & $\begin{array}{l}\text { Preval. }{ }^{3} \\
\text { n (\%) }\end{array}$ & Guidelines & $\begin{array}{l}\text { Alternative to } \\
\text { ENT }^{4}\end{array}$ & Braz. mar. pres. ${ }^{5}$ & Altern. route ${ }^{6}$ \\
\hline $\begin{array}{l}\text { Metoprolol } \\
\text { (succinate) }\end{array}$ & ert & No & $3(1.4)$ & $\begin{array}{l}\text { Risk of adverse reactions and tube obstruction. } \\
\text { Replace medication. }\end{array}$ & No & $\begin{array}{l}\text { Yes (tartrate - } \\
\text { tablet) }\end{array}$ & $\begin{array}{l}Y^{7} s^{7} \text { (tartrate } \\
\text { - IV) }\end{array}$ \\
\hline Metronidazole & $\mathrm{t}$ & Yes & $3(1.4)$ & $\begin{array}{l}\text { Grind and disperse in } 10 \mathrm{~mL} \text { of DW. }{ }^{9} \text { Prefer } \\
\text { liquid formulation. }\end{array}$ & Yes $^{13}$ & Yes $^{13}$ & Yes $\left(I^{12}\right)$ \\
\hline $\begin{array}{l}\text { Mycophenolate } \\
\text { mofetil }\end{array}$ & $\cot$ & Yes $^{8}$ & $3(1.4)$ & $\begin{array}{l}\text { Occupational risk (the drug is teratogenic and } \\
\text { requires proper handling to minimize risk) }\end{array}$ & No & No & No \\
\hline $\begin{array}{l}\text { Mycophenolate } \\
\text { sodium }\end{array}$ & ect & No & $1(0.5)$ & $\begin{array}{l}\text { Occupational risk (teratogenic drug) and tube } \\
\text { obstruction. }\end{array}$ & No & No & No \\
\hline $\begin{array}{l}\text { Isosorbide } \\
\text { mononitrate }\end{array}$ & $\mathrm{t}$ & Yes & $2(0.9)$ & $\begin{array}{l}\text { Disperse in } 20 \mathrm{~mL} \text { of DW. }{ }^{9} \text { Greater absorption } \\
\text { can occur with the risk of adverse effects. } \\
\text { Consider starting with a reduced dose. }\end{array}$ & No & No & Yes $\left(I^{12}\right)$ \\
\hline Morphine & $\mathrm{t}$ & Yes & $3(1.4)$ & Grind and disperse in $10 \mathrm{~mL}$ of DW. ${ }^{9}$ & No & $\begin{array}{l}\text { Yes (oral sol./ } \\
\text { drop) }\end{array}$ & Yes $\left(I^{12}\right)$ \\
\hline Ondansetron & $\cot$ & Yes & $1(0.5)$ & Disperse in $10 \mathrm{~mL}$ of DW. ${ }^{9}$ & No & $\begin{array}{l}\text { Yes } \\
\text { (orodispersible } \\
\text { tablet) }\end{array}$ & Yes $\left(\mathrm{IV}^{12}\right)$ \\
\hline Paracetamol & $\mathrm{t}$ & Yes & $2(0.9)$ & Disperse in $10 \mathrm{~mL}$ of DW. ${ }^{9}$ & $\begin{array}{l}\text { Yes (oral sol./ } \\
\text { drop) }\end{array}$ & $\begin{array}{l}\text { Yes (oral sol./ } \\
\text { drop) }\end{array}$ & No \\
\hline Prednisone & $\mathrm{t}$ & Yes & $3(1.4)$ & $\begin{array}{l}\text { Grind and disperse in } 10 \mathrm{~mL} \text { of DW. }{ }^{9} \text { Administer } \\
\text { with } \mathrm{EN} .{ }^{10}\end{array}$ & Yes $^{14}$ & Yes $^{14}$ & No \\
\hline Propatylnitrate & st & Yes & $5(2.3)$ & $\begin{array}{l}\text { Disperse in } 10 \mathrm{~mL} \text { of DW. }{ }^{9} \text { Effect can be } \\
\text { reduced. }\end{array}$ & No & No & No \\
\hline Racecadotril & cap & No & $2(0.9)$ & $\begin{array}{l}\text { Risk of tube obstruction. Prefer powder } \\
\text { formulation. }\end{array}$ & No & $\begin{array}{l}\text { Yes (oral } \\
\text { solution) }\end{array}$ & No \\
\hline Ranitidine & $\cot$ & No & $3(1.4)$ & $\begin{array}{l}\text { Risk of tube obstruction by the coating. } \\
\text { Replace with liquid formulation. }\end{array}$ & $\begin{array}{l}\text { Yes (oral } \\
\text { solution) }\end{array}$ & $\begin{array}{l}\text { Yes (oral } \\
\text { solution) }\end{array}$ & Yes (IV'12) \\
\hline Rifampicin & cap & No & $2(0.9)$ & $\begin{array}{l}\text { There are no data available in the literature } \\
\text { consulted. Prefer liquid formulation. }\end{array}$ & $\begin{array}{l}\text { Yes (oral } \\
\text { suspension) }\end{array}$ & $\begin{array}{l}\text { Yes (oral } \\
\text { suspension) }\end{array}$ & No \\
\hline Risperidone & $\cot$ & Yes & $19(7.8)$ & Disperse in $10 \mathrm{~mL}$ of DW. ${ }^{9}$ & No & $\begin{array}{l}\text { Yes (oral } \\
\text { solution) }\end{array}$ & No \\
\hline $\begin{array}{l}\text { Saccharomyces } \\
\text { boulardii }\end{array}$ & cap & Yes & $2(0.9)$ & $\begin{array}{l}\text { Disperse the contents of the capsule in } 10 \mathrm{~mL} \\
\text { of DW. } .^{9}\end{array}$ & $\begin{array}{l}\text { Yes (oral } \\
\text { powder) }\end{array}$ & $\begin{array}{l}\text { Yes (oral } \\
\text { powder) }\end{array}$ & No \\
\hline Secnidazole & $\mathrm{t}$ & Yes & $3(1.4)$ & Disperse in $10 \mathrm{~mL}$ of DW. ${ }^{9}$ & No & $\begin{array}{l}\text { Yes (oral } \\
\text { suspension) }\end{array}$ & No \\
\hline Simvastatin & $\cot$ & Yes & $6(2.8)$ & $\begin{array}{l}\text { Disperse in } 10 \mathrm{~mL} \text { of DW. }{ }^{9} \text { Avoid introducing } \\
\text { the coating into the tube. }\end{array}$ & No & No & No \\
\hline $\begin{array}{l}\text { Sulfamethoxazole } \\
+ \text { trimethoprim }\end{array}$ & $\mathrm{t}$ & No & $3(1.4)$ & $\begin{array}{l}\text { Risk of tube obstruction. Prefer liquid } \\
\text { formulation. }\end{array}$ & Yes (oral susp.) & Yes (oral susp.) & Yes $\left(I^{12}\right)$ \\
\hline Tacrolimus & cap & Yes & $4(1.8)$ & $\begin{array}{l}\text { Disperse the contents of the capsule in } 15 \\
\mathrm{~mL} \text { of } \mathrm{DW}^{9} \text { and administer } 1 \text { hour before or } 2 \\
\text { hours after the diet, incompatible with PVC. }\end{array}$ & No & No & No \\
\hline Topiramate & $\cot$ & Yes & $3(1.4)$ & Grind and disperse in $10 \mathrm{~mL}$ of DW. ${ }^{9}$ & No & No & No \\
\hline
\end{tabular}

${ }^{1}$ Presentation: Tablet (t), Chewable tablet (ct), Coated tablet (cot), Enteric coated tablet (ect), Extended-release tablet (ert), Sublingual tablet (st), Capsule (cap), Dragée (dg). ${ }^{2}$ Can it be administered through a tube? ${ }^{3}$ Prevalence. ${ }^{4}$ Alternative presentation for standardized ENT administration in the hospital under study. ${ }^{5}$ Alternative presentation in the Brazilian market. ${ }^{6}$ There administered though tube? Prevalen. "Alternative prestion is a presentation for administration through the standardized alternative route. There are no studies in the literature showing the effectiveness and safety of prolonged use of the injectable solution of metoprolol tartrate. The literature consulted recommends the administration by tube provided that preparation is carried out in an appropriate manner (use of biological safety cabin and personal protective equipment) to reduce risk to the handler. ${ }^{9}$ Distilled Water (DW). ${ }^{10}$ Enteral Nutrition (EN). ${ }^{11}$ Pharmacokinetics can be altered, but there are no reports of adverse
effects resulting in the literature consulted. ${ }^{12}$ Intravenous (IV). ${ }^{13}$ Alternative: oral suspension of benzoylmethronidazole. ${ }^{14}$ Liquid alternative: oral prednisolone solution.

In this study, prescriptions for solid medications by tubes were not associated with the demographic and clinical characteristics of the patients. Our data indicate that such off-label prescriptions for solid pharmaceutical forms are similarly distributed among patients of both genders, aged and not aged, clinically severe and non-severe, and who had a discharge or death outcome. However, the reduced sample size may have impacted on the result in the analyses.

Administration of medications by ENTs is preferable to parenteral use, as the former is less associated with infections and has a lower comparative cost. ${ }^{34}$ However, it is considered off-label for most of the available oral solids, leading to use based on limited evidence, which does not guarantee that it is an effective and safe practice. In addition to that, there is risk for the professionals involved in the process of using medications in this way because, as there is no support for crushing and dispersing solid pharmaceutical forms by the industries, the legal responsibility rests entirely with those who prescribe and administer. ${ }^{4}$

The prescription frequency of solid drugs by tubes in this study was similar to that found in a study conducted in Iran..$^{35}$ It is important to note that this practice increases the risk of tube obstruction, especially those of smaller diameter, generally used because they cause less discomfort in the patient. This adverse event requires more time for the assistance team to unblock/change the device, increasing costs, prolonging the pause in the administration of diet and medication, and can further compromise the condition of the critically-ill patient. ${ }^{3,36}$ 
The mean oral solids per patient was similar to the 4.7 reported by an Iranian study with critically-ill patients..$^{35}$ Heineck, Bueno and Heydrich (2009) ${ }^{37}$ showed that there is a direct correlation between the administration of medications by tubes and the number of ENT exchanges. The authors associated the administration of five or more drugs per tube and more than 13 administrations per day with greater need for ENT replacement. ${ }^{37}$ The literature shows that this practice is frequent ${ }^{24,35,37}$ and is due to factors such as the lack of available alternative formulations, to the team's lack of knowledge about the availability of the same drug in another pharmaceutical form, and to lack of knowledge about the contraindications of certain formulations for use by tube. ${ }^{38,39}$

In our study, there was a $21.6 \%(n=11)$ rate of solid pharmaceutical preparations with contraindication for administration by tube; therefore, there is no restriction on use by the route prescribed for most of the oral solids chosen. This result is similar to that reported by other authors in an intensive care setting. ${ }^{29,39}$ However there was prescription of formulations such as sublingual tablets, with enteric coating and prolonged release and PDM.

Sublingual tablets are used for substances that undergo extensive first-pass metabolism. Enteric coated preparations aim to avoid irritation of the gastric mucosa or to protect drugs from degradation in the stomach, these being released only in the intestine. ${ }^{38}$ In this way, the administration of these formulations by tubes can result ineffective. In the case of gastro-resistant forms, this will depend on the position of the ENT. ${ }^{38}$ Longer-release tablets, on the other hand, aim for a slower release of the drug, allowing for less frequency of administration and higher doses of the drug in the medication. The administration by tube of this type of formulation results in immediate drug release, which can lead to toxic serum levels and tube obstruction by excipients..$^{38}$ On the other hand, the use of PDMs by tubes, such as morphine, can cause serious clinical consequences for the patient. Even when the use of a PDM by tube is not contraindicated, its administration requires special attention and greater surveillance. ${ }^{40}$

Interactions between drugs and diet are also a potential threat to the effectiveness and safety of the drug and nutritional therapies. Several types of interactions can occur, such as physiological, which frequently results in gastrointestinal intolerance and is sometimes associated only with enteral diet. ${ }^{25,41}$ There is also pharmacokinetic interaction, in which absorption, distribution, biotransformation or excretion can be altered. This is the case for digoxin, whose absorption is reduced when there is concomitant administration with diets high in fibers. ${ }^{25}$

Among the solid preparations, there was predominance of immediate-release tablets, whose formulation itself does not have any contraindications for administration by enteral tube, a result consistent with the literature. ${ }^{29,30}$ Despite this, the use of these medications is not risk-free. First of all, adequate handling is necessary to ensure the physical-chemical and microbiological stability of the extemporaneous preparation. ${ }^{42} \mathrm{~A}$ preparation method that minimizes drug loss must be adopted before administration, as well as the use of tubes made with compatible materials, as significant loss of tablet mass can occur, especially during the passage through the ENT. ${ }^{43}$

It is also important to know the distal position of the tube and the absorption sites of each substance. One of the drugs most frequently prescribed in the present study was acetylsalicylic acid, which requires an acidic $\mathrm{pH}$ to be absorbed. Thus, its administration by tube in a post-pyloric position would lead to possible therapeutic ineffectiveness. ${ }^{44}$ However, it is necessary to emphasize that the patient's clinical condition will not always allow for total adaptation to what is recommended, and the case must be evaluated to determine the most appropriate conduct.

The frequency of prescriptions with oral liquid forms was $28.6 \%$, above the $10 \%$ found by Triki and collaborators (2012). ${ }^{45}$ In addition to that, there was a standard liquid formulation for $25.5 \%$ of the prescribed solid forms. Also considering those that are not standardized, but with liquid formulations existing on the market, this value reaches $43.1 \%$. The administration of oral fluids by ENT is preferable because it reduces the chance of obstruction and the time spent preparing the medication, as well as it provides greater safety. However, factors such as viscosity, osmolality and $\mathrm{pH}$ can contribute to tube obstruction and to the occurrence of adverse reactions including diarrhea, nausea, vomiting and bloating. ${ }^{34,38}$

Many liquid formulations contain sorbitol, a potent osmotic laxative, to improve the palatability of the product. Many liquid formulations contain sorbitol, a potent osmotic laxative, to improve the palatability of the product. Considering that liquid formulations are generally designed for pediatric populations and, therefore, contain drugs in low concentrations for better dose adjustment, the volumes required for adults lead to exposure to large amounts of this excipient, increasing the risk of ADRs in these patients. ${ }^{34}$

Among the most prescribed drugs are carvedilol, amiodarone, amlodipine and hydralazine. In this study, drugs for the cardiovascular system without alternative liquid formulations were the most frequently prescribed. For this group of drugs, the options for alternative formulations are restricted, which forces the health care team to rely on empirical recommendations and on the patient's clinical and laboratory parameters to determine whether the treatment is effective and safe. ${ }^{4}$ Use of injectable presentations was also identified $(2.8 \%, n=9)$, a value similar to that found in a Tunisian study. ${ }^{42}$ As they are not developed for administration by enteral route, intravenous formulations can have high osmolality or contain excipients that cause osmotic diarrhea, such as propylene glycol. ${ }^{38}$

It is important to note that many of the aforementioned adverse events can be avoided by applying institutional protocols for administering medications by ENTs, prioritizing the use of liquid formulations, especially emulsions and elixirs, dilution of those with greater osmolality and viscosity, correct preparation of the solid pharmaceutical forms, verification of tube position, ensuring that the drugs chosen have adequate absorption and bioavailability. In addition, the adoption of the correct administration procedure, including washing the tube with distilled water before, during and after the infusion, minimizes the likelihood of diarrhea due to the use of contaminated water and precipitation due to the interaction of the substance with the diet. ${ }^{26}$

The inconsistencies between what is recommended in the literature and what is performed by the professionals involved in the process, evidenced in this study, were also observed by other researchers, resulting in practices that threaten patient safety. ${ }^{39,46}$ However, it was possible to observe a low prescription frequency of medications such as prednisone (tablet) and enteric coated sodium mycophenolate, each prescribed for a maximum of one day and for which there are more suitable standardized substitutes in the hospital (prednisolone and mycophenolate mofetil, respectively).

In a study carried out in two Iranian hospitals, it was possible to observe an improvement in the knowledge of the Nursing team regarding the adequacy of the administration of solid oral medications by ENT using educational actions led by the clinical pharmacist. ${ }^{47}$ Therefore, 
it is essential to enable the presence of a clinical pharmacist and the continuous training of the assistance team to promote the use of the appropriate pharmaceutical forms, when these are available at the institution, as well as the risk-benefit assessment of the administration by tube of preparations with restrictions. ${ }^{10}$

In this study, just over $10 \%$ of the drugs prescribed by tube were considered PDMs. Although the frequency of this use was not high, this finding can indicate a greater need for patient surveillance. If used incorrectly, PDMs increase the risk of causing serious medical consequences to the patients. Therefore, these medications are potentially subjected to greater institutional surveillance and their use in unregulated conditions (off-label) tends to be less frequent in the clinical practice. ${ }^{48}$

Our study provides valuable information on the off-label use of medications by critically-ill adult patients, in addition to providing practical administration guidelines. However, it does have some limitations. In the first place, data on the prevalence of medication prescription by tube cannot be generalized to community or rural hospitals, institutions without the daily presence of the pharmacist in the ICU units, and non-adult ICU populations. In addition to that, this was a single-center study carried out in a short period of time and with a reduced sample size, without evaluating the benefits and adverse effects associated with the use of medications by enteral tube. Future studies in different health centers must be conducted to elucidate those gaps.

\section{Conclusion}

In this study, a high frequency of prescription by enteral tube of medications for the cardiovascular system was observed, in solid pharmaceutical forms, with a predominance of immediate-release tablets, and without alternative formulations such as carvedilol, amiodarone and amlodipine. In this way, the guidelines on proper administration by tube of the medications found aid in decisionmaking about the risks and benefits of using them in patients with tubes, promoting greater safety for those involved in this process.

\section{Funding sources}

The research did not receive funding for its realization.

\section{Collaborators}

Project conception: GAA, EFC, JAN, MMG, MPP. Data analysis and interpretation: GAA, EFC, JAN, JVS. Data collection: EFC, JVS. Writing of the article and responsibility for all the information presented in the paper, ensuring accuracy and integrity of any of its parts: GAA, EFC. Relevant critical review of the intellectual content and final approval of the version to be published: $M M G$, MPB.

\section{Acknowledgments}

The authors are grateful for the contribution of the physicians and pharmacists of the Walter Cantídio University Hospital who collaborated in the conduction of this study.

\section{Conflict of interests statement}

The authors declare that there are no conflicts of interest in relation to this article.

\section{References}

1. Medscape. Medication administration through enteral feeding tubes. Available from: https://www.medscape.com/ viewarticle/585397. Accessed on: 14 de out 2019.

2. Oliveira ACM, Friche AAL, Salomão MS, et al. Predictive factors for oropharyngeal dysphagia after prolonged orotracheal intubation. Braz J Otorhinolaryngol. 2018;84(6):722-28.

3. Williams NT. Medication administration through enteral feeding tubes. Am J Health Syst Phar. 2008;65(24): 2347-57.

4. Wright $D$, Griffith $\mathrm{R}$, Merriman $\mathrm{H}$, et al. Medication management of patients with nasogastric (NG), percutaneous gastrostomy (PEG), or other enteral feeding tubes. Guidelines 2019. Available from: https://www.guidelines.co.uk/dysphagia/medication-management-of-patients-with-enteral-feeding-tubes/454634.article. Accessed on: 23 de out 2019.

5. Beserra MPP. Método de administração de medicamentos por sonda de alimentação: desenvolvimento, validação e análise da segurança e efetividade [tese] - Fortaleza: Universidade Federal do Ceará, 2016.

6. Aronson JK, Ferner RE. Unlicensed and off-label uses of medicines: definitions and clarification of terminology. $\mathrm{Br} J$ Clin Pharmacol. 2017;83(12): 2615-2625.

7. Smithburger PL, Buckley MS, Culver MA, et al. A multicenter evaluation of off-label medication use and associated adverse drug reactions in adult medical i. Crit Care Med. 2015;43(8):1612-21.

8. Shoulders BR, Smithburger PL, Tchen S, et al. Characterization of Guideline Evidence for Off-label Medication Use in the Intensive Care Unit. Ann Pharmacother. 2017;51(7):529-42.

9. Aagaard L. Off-label and unlicensed prescribing of medicines in paediatric populations: occurrence and safety aspects. Basic Clin Pharmacol Toxicol. 2015;117:215-8.

10. Hossaini AS, Ghorbani R, Vazin A. Improving knowledge, attitudes, and practice of nurses in medication administration through enteral feeding tubes by clinical pharmacists: a casecontrol study. Adv Med Educ Pract. 2019;10:493-500.

11. Knaus WA, Draper EA, Wagner DP, et al. APACHE II: a severity of disease classification system. Crit Care Med. 1995;13:818-29.

12. Vincent JL, Moreno R, Takala J, et al. The SOFA (Sepsis-related Organ Failure Assessment) score to describe organ dysfunction/failure. Intensive Care Med. 1996;22:707-10.

13. World Health Organization. The anatomical therapeutic chemical classification system with defined daily doses (ATC) DDD). Norway: WHO. 2006. Available from: https ://www. whocc.no/atc_ddd_index/. Accessed on: 01 Jan 2018.

14. Instituto para Práticas Seguras no Uso de Medicamentos. Medicamentos Potencialmente Perigosos de Uso Hospitalar e Ambulatorial- Listas Atualizadas 2015. Boletim ISMP Brasil. 2015; 4(3). Available from: <http://www.ismp-brasil.org/site/ wp-content/uploads/2015/12/V4N3.pdf>. Accessed on: 12 Out 2019.

15. Micromedex Healthcare Series [Internet]. Do not crush list [Internet]. Available from: https://www.micromedexsolutions. com/micromedex2/librarian/. Accessed on: 13 out 2019. 
16. Micromedex Healthcare Series [Internet]. Enteral feeding tubes and enteral delivery [Internet]. Available from: https:// www.micromedexsolutions.com/micromedex2/librarian/. Accessed on: 13 out 2019.

17. Institute for Safe Medication Practices (ISMP). Oral dosage forms that should not be crushed [Internet]. Available from: https://www.ismp.org/recommendations/do-not-crush. Accessed on: 13 out 2019

18. Brasil. Ministério da Saúde. Bulário eletrônico [Internet]. Available from: http://www.anvisa.gov.br/datavisa/fila_bula/ index.asp. Accessed on: 25 out 2019.

19. Lima G, Negrini NMM. Assistência farmacêutica na administração de medicamentos via sonda: escolha da forma farmacêutica adequada. Einstein. 2009;7(1):9-17.

20. Gorzoni ML, Torre AD, Pires SL. Medicamentos e sondas de nutrição. Rev Assoc Med Bras. 2010;56(1):17-21.

21. Brasil. Ministério da Saúde. Lista de Medicamentos de Referência [Internet]. Available from: http://www.portal. anvisa.gov.br. Accessed on: 13 out 2019.

22. Brasil. Ministério da Saúde. Lista de Medicamentos Genéricos [Internet]. Available from:http://www.portal.anvisa.gov. br. Accessed on: 13 out 2019.

23. Brasil. Ministério da Saúde. Lista de Medicamentos Similares [Internet]. Available from: http://www.portal.anvisa.gov.br. Accessed on: 13 out 2019

24. Silva MFB, Brito PD, Guaraldo L. Medicamentos orais de uma unidade hospitalar: adequação ao uso por cateteres enterais. Rev Bras Enferm. 2016;69(5):847-54.

25. Jiménez RMR, Navarro CO, Compés CC. La polifarmacia del paciente crónico complejo y la nutrición enteral. Nutr Hosp. 2017;34(1):57-76.

26. White R, Bradnam V. Handbook of drug administration via enteral feeding tubes. 3 ed. Londres: Pharmaceutical Press, 2015.

27. Gonçalves MG, Heineck I. Frequency of prescriptions of off-label drugs and drugs not approved for pediatric use in primary health care in a southern municipality of Brazil. Rev Paul Pediatr. 2016;34(1):11-17.

28. Souza AS, Santos DB, Rey LC, et al. Off-label use and harmful potential of drugs in a NICU in Brazil: A descriptive study. BMC Pediatrics. 2016;16(1):1-10.

29. Martins MR, Soares AQ, Modesto ACF, et al. Análise de medicamentos administrados por sonda em unidades de terapia intensiva em hospital de ensino. Rev Eletr Enf [Internet]. 2013;15(1):191-6.

30. Souza MRNS, Contarine LM, Barreto JBC, et al. Obstrução do cateter de nutrição enteral e a administração de fármacos sólidos na unidade de terapia intensiva adulto. Persp Online: Biol \& Saúde. 2018;8(26):42-53.

31. Bastos AS, Beccaria LM, Silva DC, et al. Identification of delirium and subsyndromal delirium in intensive care patients. Rev Bras de Enferm. 2019;72(2):463-7.

32. Guerra TLS, Mendonça SS, Marshall NG. Incidência de constipação intestinal em uma unidade de terapia intensiva. Rev Bras Ter Intensiva. 2013;25(2):87-92
33. Ribeiro ALP, Duncan BB, Brant LCC, et al. Cardiovascular health in Brazil: trends and perspectives. Circulation. 2016;133(4):422-33.

34. Bandy KS, Albrecht S, Parag B. Practices Involved in the Enteral Delivery of Drugs. Curr Nutr Rep. 2019;16.

35. Sohrevardi SM, Jarahzadeh MH, Mirzaei E, et al. Medication errors in patients with enteral feeding tubes in the intensive care unit. J Res Pharm Pract. 2017;6(2):100-5.

36. Kurien M, Penny H, Sanders DS. Impact of direct drug delivery via gastric access devices. Expert Opin Drug Deliv. 2014;12(3):455-63.

37. Heineck I, Bueno D, Heydrich J. Study on the use of drugs in patients with enteral feeding tubes. Pharm World Sci. 2009;31:145-8.

38. Matysiak-Luśnia K, Łysenko L. Drug administration via enteral feeding tubes in intensive therapy - terra incognita? Anaesthesiol Intensive Ther. 2014;46(4):307-11.

39. Demirkan K, Bayraktar-Ekincioglu A, Gulhan-Halil M, et al. Assessment of drug administration via feeding tube and the knowledge of health-care professionals in a university hospital. Eur J Clin Nutr. 2017;71:164-8.

40. Anacleto TA, Nascimento MMG, Rosa MB, et al. Medicamentos potencialmente perigosos de uso hospitalar - lista atualizada 2019. Boletim ISMP Brasil. 2019;8(1).

41. Brito-Ashurst I, Preiser JC. Diarrhea in Critically III Patients: The Role of Enteral Feeding. J Parenter Enteral Nutr. 2016;40(7):913-23.

42. Haywood A, Glass BD. Liquid dosage forms extemporaneously prepared from commercially available products considering new evidence on stability. J Pharm Pharm Sci. 2013;16(3):441-5.

43. Ruzsíková A, Soucková L, Suk P, et al. Quantitative analysis of drug losses administered via nasogastric tube - In vitro study. Int J Pharmaceut. 2015;478(1):368-71.

44. McIntyre CM, Monk HM. Medication absorption considerations in patients with postpyloric enteral feeding tubes. Am J Health Syst Pharm. 2014;71:549-56.

45. Triki E, Fendri S, Dammak H, et al. Administration des médicaments par sonde de nutrition entérale: évaluation dês pratiques dans un service de réanimation médicale d'un hôpital tunisien. AFAR. 2012; 31:596-99.

46. Sari D, Kadifeli $D$, Akbiyik A, et al. Intensive care unit nurses' knowledge of medication administration via enteral tubes. Nurs Crit Care. 2018;23(3):141-6.

47. Dashti-Khavidaki S, Badri S, Eftekharzadeh SZ, et al. The role of clinical pharmacist to improve medication administration through enteral feeding tubes by nurses. Int J Clin Pharm. 2012;34:757-64.

48. Cajanding JMR. Administering and monitoring high-alert medications in acute care. Nurs Stand. 2017;31(47):42-52.

49. BRASIL. Ministério da Saúde. Ordinance No. 2,528, dated Thursday, October 19, 2006. Brasília: Diário Oficial [da] República Federativa do Brasil, 2006. 